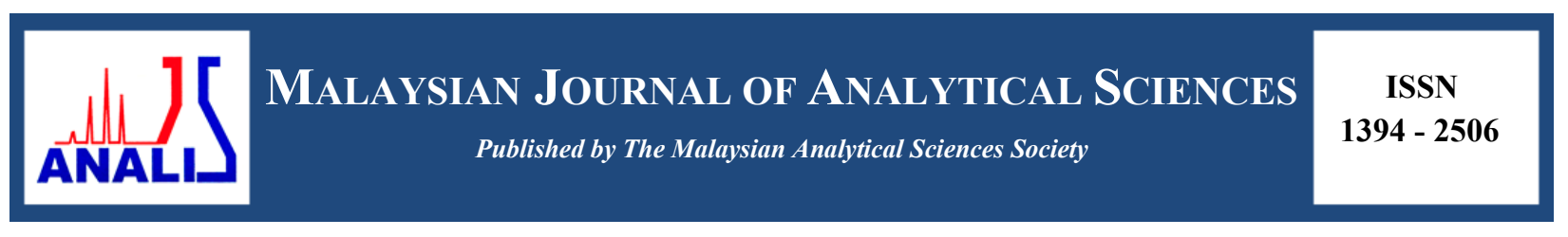

\title{
SYNTHESIS AND CHARACTERIZATION OF HYDROXYAPATITE NANOPARTICLE
}

\author{
(Sintesis dan Pencirian Nanozarah Hidrosiapatit) \\ Sahlil Miraz Mohamed Rafie* and Darman Nordin \\ Department of Chemical and Process Engineering, \\ Faculty of Engineering and Built Environment, \\ Universiti Kebangsaan Malaysia, 43600 UKM Bangi, Selangor, Malaysia \\ *Corresponding author: sahlilmiraz.rafie@gmail.com
}

Received: 21 October 2015; Accepted: 14 June 2016

\begin{abstract}
In this research, hydroxyapatite (HA) nano-size powder was synthesized using wet chemical precipitation technique under atmospheric pressure where calcium hydroxide $\left(\mathrm{Ca}(\mathrm{OH})_{2}\right)$ and ortho-phosphoric acid $\left(\mathrm{H}_{3} \mathrm{PO}_{4}\right)$ were used as precursors. Distilled water was used as a diluting media for the reaction and sodium hydroxide $(\mathrm{NaOH})$ was used to control the initial $\mathrm{pH}$. The initial $\mathrm{pH}$ values, reaction temperature and calcined temperature play an important role in the morphology on HA as well as the phase formation and degree of crystallinity. Nano HA powder has been studied at different initial $\mathrm{pH}$ value which is between 9.00 to 11.00 , reaction temperature from $80{ }^{\circ} \mathrm{C}$ to $100^{\circ} \mathrm{C}$ and calcined temperature at $700{ }^{\circ} \mathrm{C}$ to $800{ }^{\circ} \mathrm{C}$. The optimum initial pH value was found at $\mathrm{pH} 10.00$, reaction temperature at $100{ }^{\circ} \mathrm{C}$ and calcined temperature was at $800{ }^{\circ} \mathrm{C}$. The crystallographic properties were evaluated by X-ray diffraction (XRD), Fourier Transform Infrared (FTIR) and Field Emission Scanning Microscope (FESEM). The Design Expert version 9.0.2 with statistical and graphical analysis of the result, by using analysis of variance (ANOVA) was applied to optimize variable in the process of synthesis of HA. Based on analysis of variance (ANOVA) that has been perform, calcined temperature was to be influential variables on mass of HA with value of probability less than 0.05 .
\end{abstract}

Keywords: hydroxyapatite, chemical precipitation, crystallinity, morphology, optimization

\begin{abstract}
Abstrak
Dalam kajian ini, nanozarah hidroksiapatit (HA) dihasilkan melalui kaedah pemendakan di bawah tekanan atmosfera di mana kalsium hidroksida $\left(\mathrm{Ca}(\mathrm{OH})_{2}\right)$ dan asid orto fosforik $\left(\mathrm{H}_{3} \mathrm{PO}_{4}\right)$ merupakan larutan asas bagi penyediaan HA. Air suling digunakan sebagai agen pelarut dalam menyediakan larutan asas bagi proses pemendakan ini. Larutan natrium hidroksida di gunakan bagi mengawal nilai $\mathrm{pH}$. Nilai $\mathrm{pH}$, suhu tindak balas dan suhu relau merupakan faktor penting dalam pencirian dan penghabluran nanozarah HA. Nanozarah HA disediakan pada nilai $\mathrm{pH}$ antara 9.00 hingga 11.00 , suhu tindak balas $80{ }^{\circ} \mathrm{C}$ hingga $100{ }^{\circ} \mathrm{C}$ dan suhu relau pada $700{ }^{\circ} \mathrm{C}$ hingga $800{ }^{\circ} \mathrm{C}$. Pencirian nanozarah HA di uji menggunakan X-ray Difractometer (XRD), Inframerah Transformasi Fourier (FTIR), dan Mikroskop Pengimbas Pancaran Medan (FESEM). Perisian Design-Expert 9.0.2 digunakan untuk menganalisis data dan pengoptimuman penghasilan mendakan HA. Berdasarkan analisis varian (ANOVA) yang dilakukan, suhu relau merupakan pemboleh ubah yang mempengaruhi berat HA dengan nilai kemungkinan kurang dari 0.05 .
\end{abstract}

Kata kunci: hikdroksiapatit, mendakan bahan kimia, penghabluran, pencirian, pengoptimuman

\section{Introduction}

Tissue disease and defect, and bone disease are serious health condition that can affect the life for those who suffer on it. Since last four decades, various revolution has been introduced in order to make improvement of the uses of 
ceramic. This improvement is about special design ceramic for repair and reconstruction of diseased or damaged parts of the body. Ceramic used in this field is called bioceramic. Two alternative ways to replace tissue are transplantation and implantation. The advantages of bioceramic offer over transplant are availability, reproducibility and reliability. Bioceramic can be classified into two group which are bioinert (ceramic that have no influent on surrounding living tissue) and bioactive ceramic (capable of bonding with living tissue as example calcium phosphate (HA) and certain compositions of glasses. Over past few decade, synthetic hydroxyapatite (HA) has been recognize as important bone substitute materials in orthopedics and dentistry due to its biological similarity to the mineral phase of human bones [1]

Due to excellent biocompatibility and tissue bio-activity properties, hydroxyapatite (HA) which is inorganic bioceramic also known as calcium phosphate ceramic that being main inorganic composition of natural bone has been extensively investigated for medical application. Because of this reason, many techniques have been developed for synthesis of HA such as mechanochemical synthesis, combustion preparation, wet chemical deposition, electrochemical deposition, sol-gel method, hydrothermal synthesis and many more [2].

From the previous researcher, HA was successfully used in separation of protein enzymes, nucleic acid, virus and other biological molecules. HA act as a prototype for bones and teeth with proven compability, HA also widely used in medical implants [3].

The size of morphology of HA used in bone is nano-sized needle-like crystals. HA can be used in various form of shape including powders, granules, dense and porous block. There is a need to characterize the HA powder depending on desired application. Using wet synthesis technique, various parameters can be controlled such as purity, crystallinity, and morphology because different morphologies will be used in different application for example small spherical particle used in thermal spray coating while needle-shape or rod-shape used in bone repair composite material [4].

Recently, nano HA get attention from the researcher because nano HA play an important role in various biomedical application due to its unique function properties of high surface area volume ratio where its structure is ultra fine similar to natural bone. There are few method to synthesis nano HA such as chemical precipitation, spray drying, sol-gel and more. In natural bone and teeth, the nanoparticle sized of HA crystal is embedded in the collagen matrix with average length of 50 $\mathrm{nm}$. In fact, collagen is act as template in the controlled biomineralization process [5].

\section{Precipitation}

\section{Materials and Methods}

In order to obtain nano-HA by precipitation method, calcium hydroxide and ortho-phosphoric acid was used as initial precursor. The experimental involve additional of desired amount of $0.67 \mathrm{M}$ of ortho-phosphoric acid (Merck, $85 \%$ ) to desired amount of $1 \mathrm{M}$ calcium hydroxide (Merck). The chemical equation involve is:

$$
10 \mathrm{Ca}(\mathrm{OH})_{2}+6 \mathrm{H}_{3} \mathrm{PO}_{4} \longrightarrow \mathrm{Ca}_{10}\left(\mathrm{PO}_{4}\right)_{6}(\mathrm{OH})_{2}+\mathrm{H}_{2} \mathrm{O}
$$

\section{Characterization}

The crystal phase and degree of crystallinity were characterized using X-ray diffraction (XRD, D8-Advance, Bruker company, Germany) with $\mathrm{Cu} \mathrm{K} \alpha$ radiation $(\lambda=0.15408)$. The XRD data were collected at room temperature over $2 \theta$ range of $20-55^{\circ}$. Chemical characterization of nano HA was performed using Fourier Transform Infrared spectroscopy (FTIR, Thermo Scientific, Nicolet 6700) The morphology and size distribution of synthesized nano HA were investigated by using Field Emission Scanning Microscope (FESEM, Zeiss SUPRA 55VP).

\section{Statistical analysis using Design of Experiment}

Response surface methodology (RSM) with central composite design (CCD) was employed to investigate the effect of synthesis parameter process of HA response to mass of HA obtained. Three independent parameters namely, reaction temperature, $\mathrm{pH}$ value and calcined temperature at three different levels each, were employed. The parameters chosen and the levels were based on previous study $[6,7,8]$ and suitability with the condition of the product, hydroxyapatite. The experimental plan was designed and the results obtained were analyzed according to 
Design Expert version 9.0.2 software to build and evaluate models as well as to plot the three-dimensional response surface curves. The experiments is run in random in order to minimize the effects of unexpected variability in the observe responses due to irrelevant factors.

\section{XRD and FTIR study on nano HA: Effect of pH variation \\ Results and Discussion}

The effect of initial $\mathrm{pH}$ value was observed by variety the initial $\mathrm{pH}$ in range 9.00 until 11.00 at different reaction temperature which are at 80 until $100{ }^{\circ} \mathrm{C}$ and calcined temperature at $700{ }^{\circ} \mathrm{C}$. In Figure 1 it can be seen that different $\mathrm{pH}$ value will affect the peak and crystallinity in XRD pattern. The variation of initial $\mathrm{pH}$ value give effect for the peak of XRD pattern where from the result it can be observe the $\mathrm{pH} 10.00$ is most suitable value for synthesis HA where at $\mathrm{pH}$ 10.00, only peak for pure HA can be trace. In Figure 2 and Figure 3 show the peak for $\mathrm{XRD}$ for $\mathrm{pH}$ variation at reaction temperature $90{ }^{\circ} \mathrm{C}$ and $100^{\circ} \mathrm{C}$.

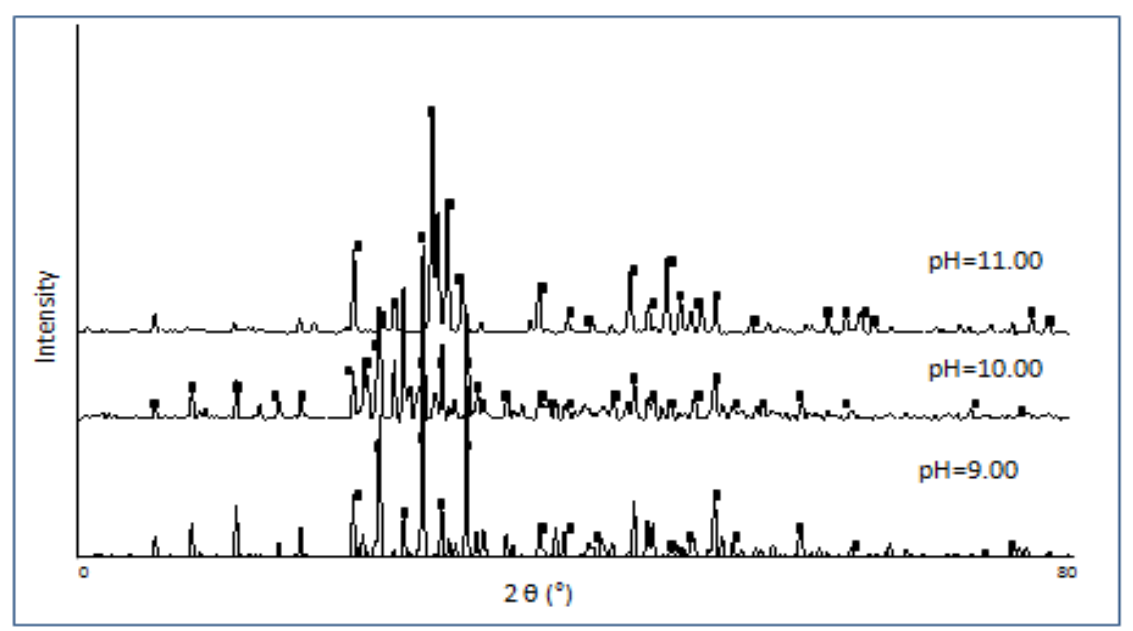

Figure 1. XRD pattern for $\mathrm{pH}$ variation at reaction temperature $80^{\circ} \mathrm{C}$ and calcined temperature $700{ }^{\circ} \mathrm{C}$

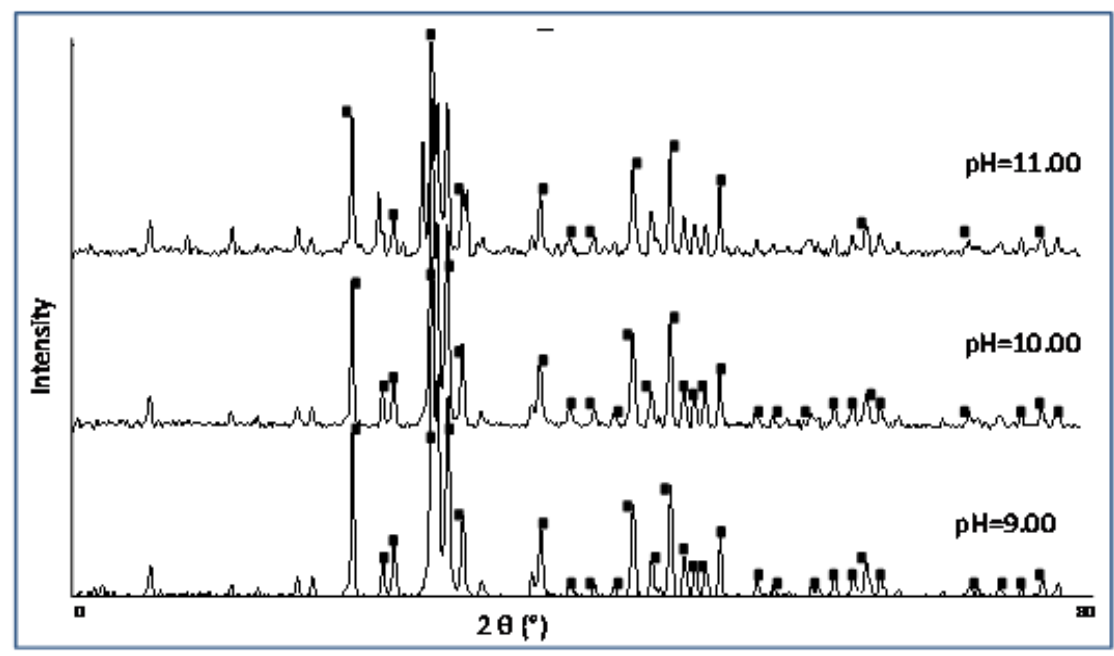

Figure 2. XRD pattern for $\mathrm{pH}$ variation at reaction temperature $90{ }^{\circ} \mathrm{C}$ and calcined temperature $700{ }^{\circ} \mathrm{C}$. 


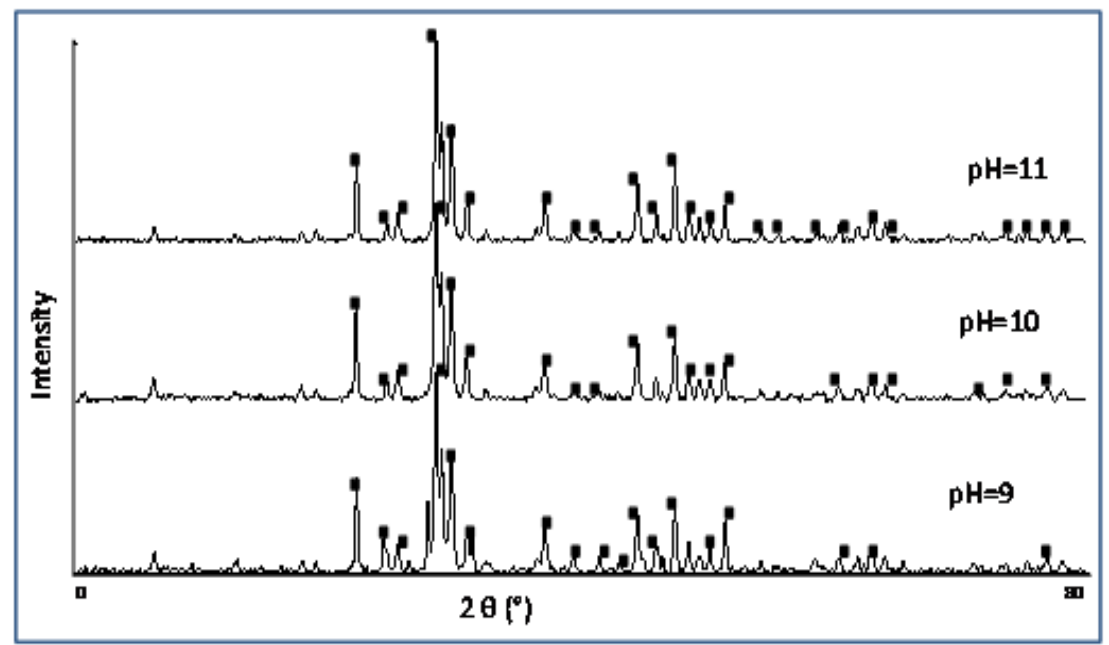

Figure 3. XRD pattern for $\mathrm{pH}$ variation at reaction temperature $100{ }^{\circ} \mathrm{C}$ and calcined temperature $700{ }^{\circ} \mathrm{C}$.

For FTIR spectra it can be observe in Figure 4 all sample have similar pattern where the sharp band at $1414 \mathrm{~cm}^{-1}$. The band $3571 \mathrm{~cm}^{-1}$ is attributed to the bending of hydroxyl group $\left(\mathrm{OH}^{-}\right)$and the band at $631 \mathrm{~cm}^{-1}$ is related to bending vibration of hydroxyl group. Characteristic of HA are found at $1457 \mathrm{~cm}^{-1}, 1414 \mathrm{~cm}^{-1}$ and $1416 \mathrm{~cm}^{-1}$ which are represent carbonate $\left(\mathrm{CO}_{3}^{2}\right)$ group.

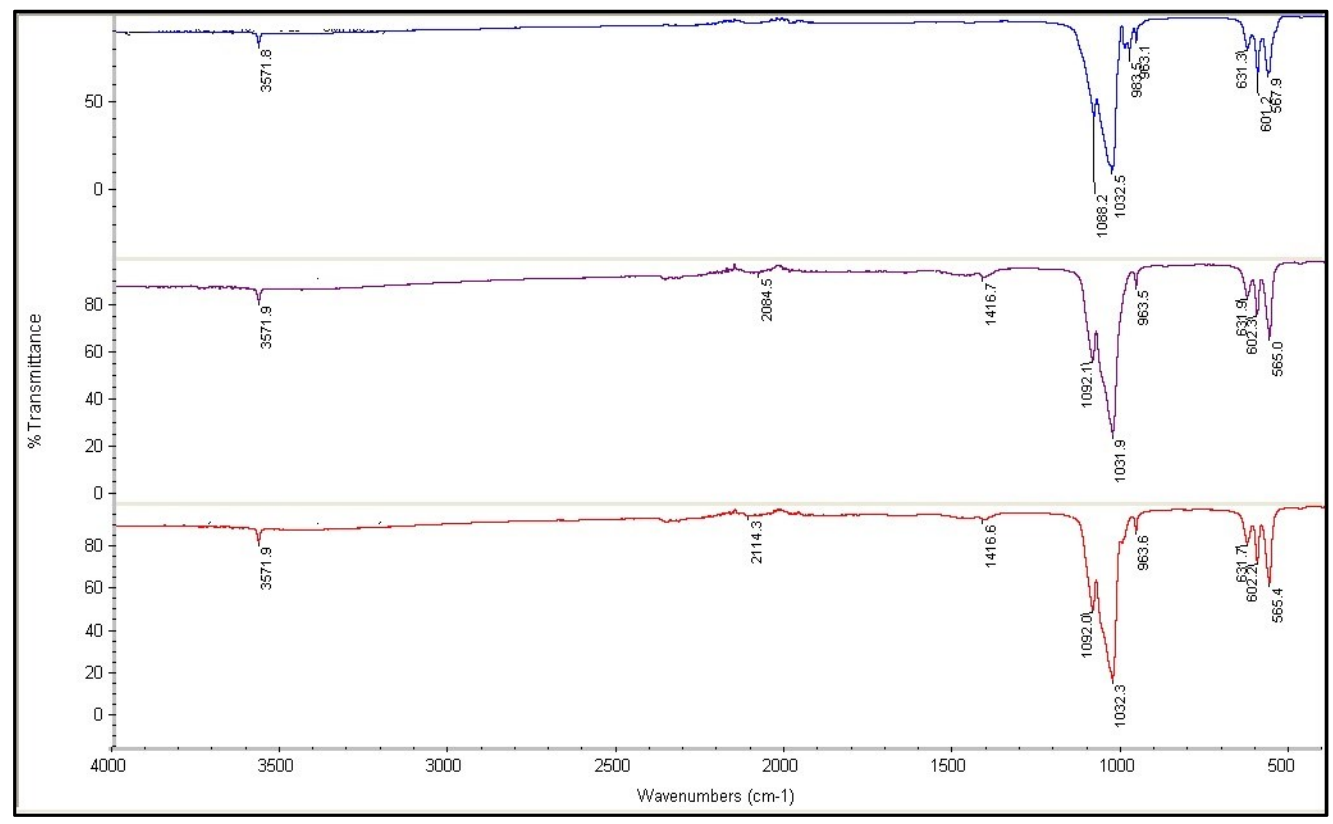

Figure 4. FT-IR spectra of nano HA at reaction temperature $80{ }^{\circ} \mathrm{C}$ and calcined temperature $700{ }^{\circ} \mathrm{C}$ 


\section{Effect of reaction temperature}

The reaction temperature for stirring also play an important role that can affect the morphology of HA. The reaction temperature was varied from $80{ }^{\circ} \mathrm{C}$ to $100{ }^{\circ} \mathrm{C}$. Temperature usually influenced the crystal phase and degree of crystallinity where during the crystallization process the reaction temperature was dependent factor on the morphology. Crystallinity is referring to the arrangement of the atom or molecules in periodic order. Depend on a certain condition, the shape of a crystal was determined by kinetics compared to thermodynamics. The kinetic of crystal face can be influenced by external factor as example supersaturation temperature and mixing [6]. All the diffraction pattern revealed peak of HA. The sharpness of the diffraction peak increase as the reaction temperature increase. Increase in sharpness of diffraction peak show increasing in crystallinity of the HA form [7].

Figure 5 shows the XRD pattern for synthesis of HA are different at different reaction temperature. The $\mathrm{pH}$ value was varied between 9.00 until 11.00 and the calcined temperature was varied from $700{ }^{\circ} \mathrm{C}$ and $800{ }^{\circ} \mathrm{C}$. From the peak pattern, it shows as the reaction temperature increase, the peak become sharper and narrow that show the increase in crystallinity of the HA. It shows that the sample at highest reaction temperature which is at $100{ }^{\circ} \mathrm{C}$ have better crystallinity of HA compared to sample at $80^{\circ} \mathrm{C}$ and $90^{\circ} \mathrm{C}$.

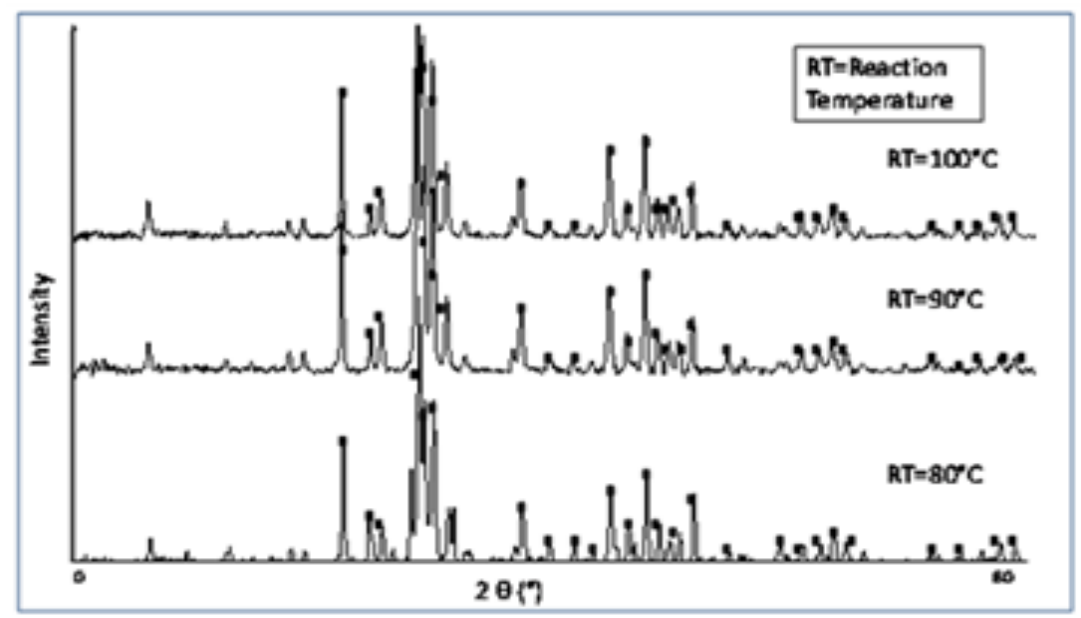

Figure 5. XRD pattern for reaction temperature variation at $\mathrm{pH} 9.00$ and calcined temperature $700{ }^{\circ} \mathrm{C}$

Figure 6 shows the FTIR spectra of HA at different reaction temperature. It can be observed that all the spectra have almost same peak where $\mathrm{PO}^{4-}$ was obtained at 565,602 and $1032 \mathrm{~cm}^{-1}$ and $\mathrm{CO}^{3-}$ was appear at 963 and 1416 . There are two shoulder peak at 631 and 3571 which are typically stretching vibration and bending mode of HA.

\section{Effect of Calcined temperature}

Other than initial $\mathrm{pH}$ value and reaction temperature, calcined temperature also play an important factor in the synthesis of HA. From the previous researcher, increase in calcined temperature will increase the crystallinity as peak become narrow and sharp moving where the temperature was varied from 100 to $800{ }^{\circ} \mathrm{C}$ [8]. It has been proven as the peak of diffraction become narrow and sharp as the calcined temperature increase from $700^{\circ} \mathrm{C}$ to 800 ${ }^{\circ} \mathrm{C}$.

The temperature for calcined was set at 700 and $800{ }^{\circ} \mathrm{C}$ at different $\mathrm{pH}$ value which are 9,10 and 11 where for reaction temperature was varied from 80,90 and $100^{\circ} \mathrm{C}$. From Figure 7 it can be observed the crystallinity of HA is increase when the temperature increase. For temperature calcined at $700{ }^{\circ} \mathrm{C}$, the peak is lower compared to HA that calcined at $800^{\circ} \mathrm{C}$. It shows that calcined temperature also be the factor of preparing the HA. 


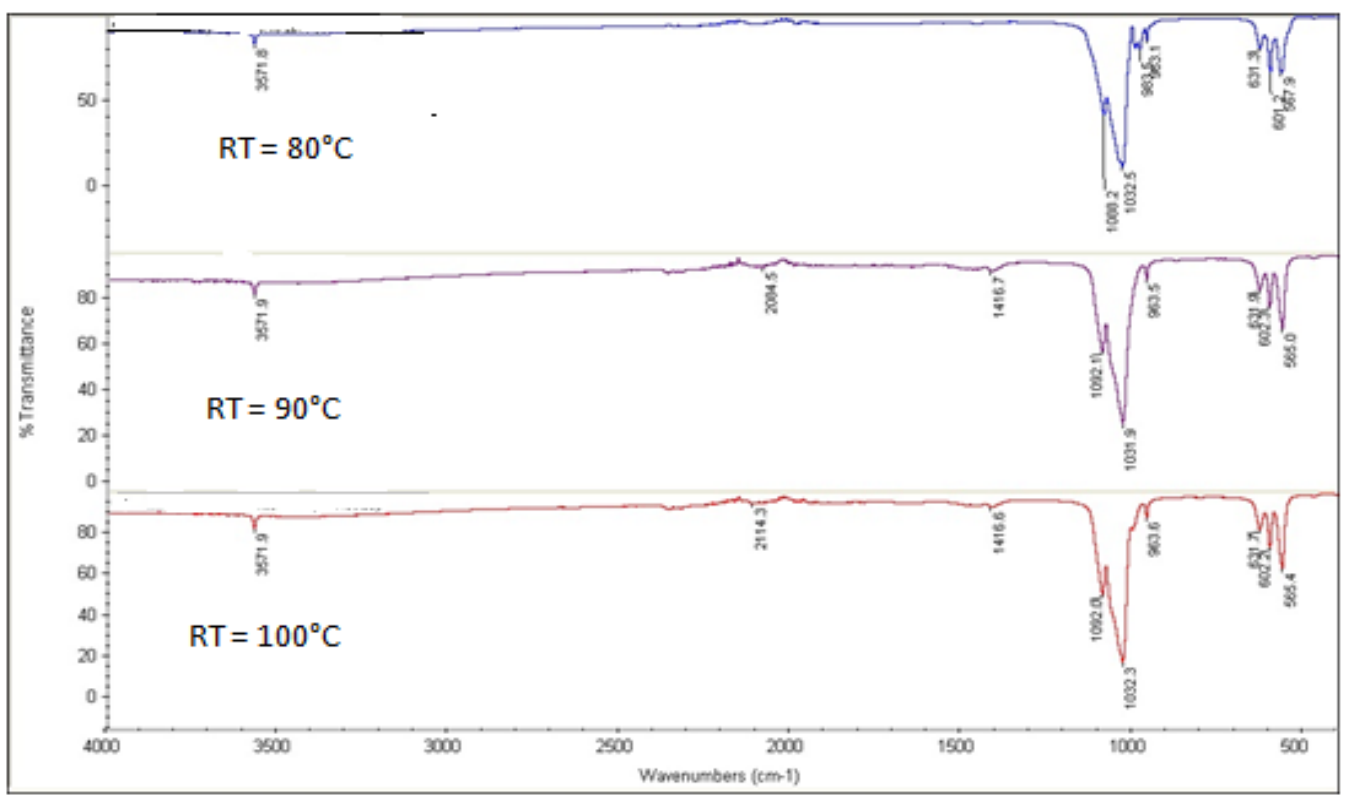

Figure 6. FT-IR spectra of nano $\mathrm{HA}$ at $\mathrm{pH}$ value 9.00 and calcined temperature $700{ }^{\circ} \mathrm{C}$

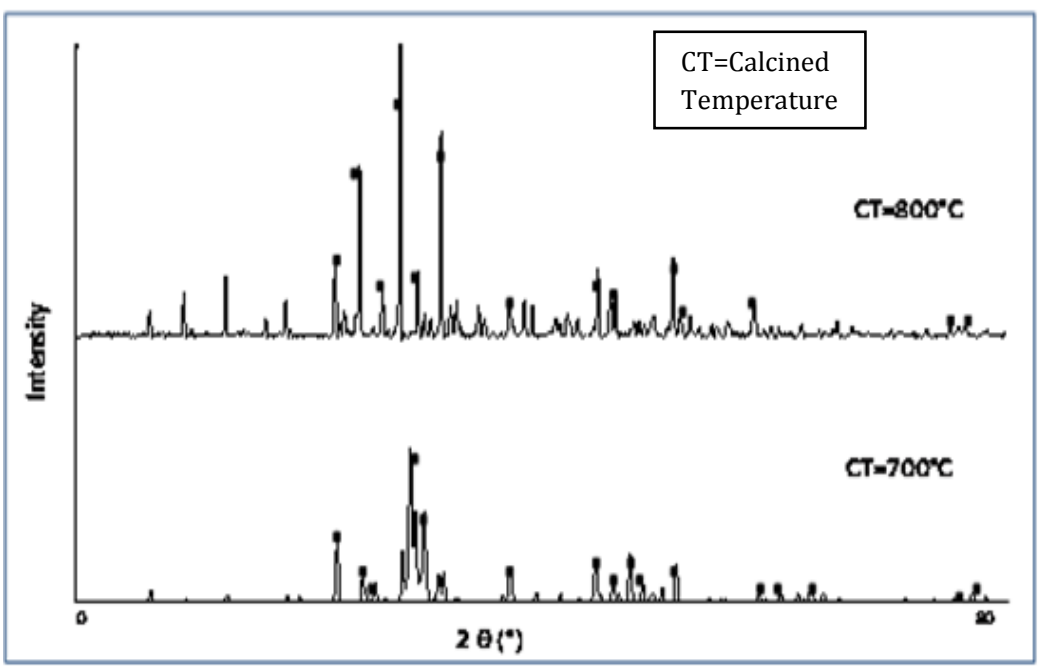

Figure 7. XRD pattern for calcined temperature variation at $\mathrm{pH} 9.00$ and reaction temperature $80{ }^{\circ} \mathrm{C}$

FTIR patterns was presented in Figure 8 The spectra possess an $\mathrm{OH}^{1-}$ group in the region of $3571 \mathrm{~cm}^{-1}$ and $\mathrm{PO}_{4}{ }^{3-}$ lies in region $1080 \mathrm{~cm}^{-1}$. So, from this analysis, the detection of HA in all sample are confirmed. The peak at $700{ }^{\circ} \mathrm{C}$ are sharper compare to $800{ }^{\circ} \mathrm{C}$. A weak band of $\mathrm{CO}_{3}$ was detect at few sample in region $1416 \mathrm{~cm}^{-1}$ and $\mathrm{H}_{2} \mathrm{O}$ also be detecting at band $1852 \mathrm{~cm}^{-1}$. As the temperature increase the peaks are going to be weak which is in agreement with published data. The characteristic band of inorganic carbonate ion suggest that carbon gets dissolve in organic from atmosphere instead of dissolve in HA crystal [8]. 


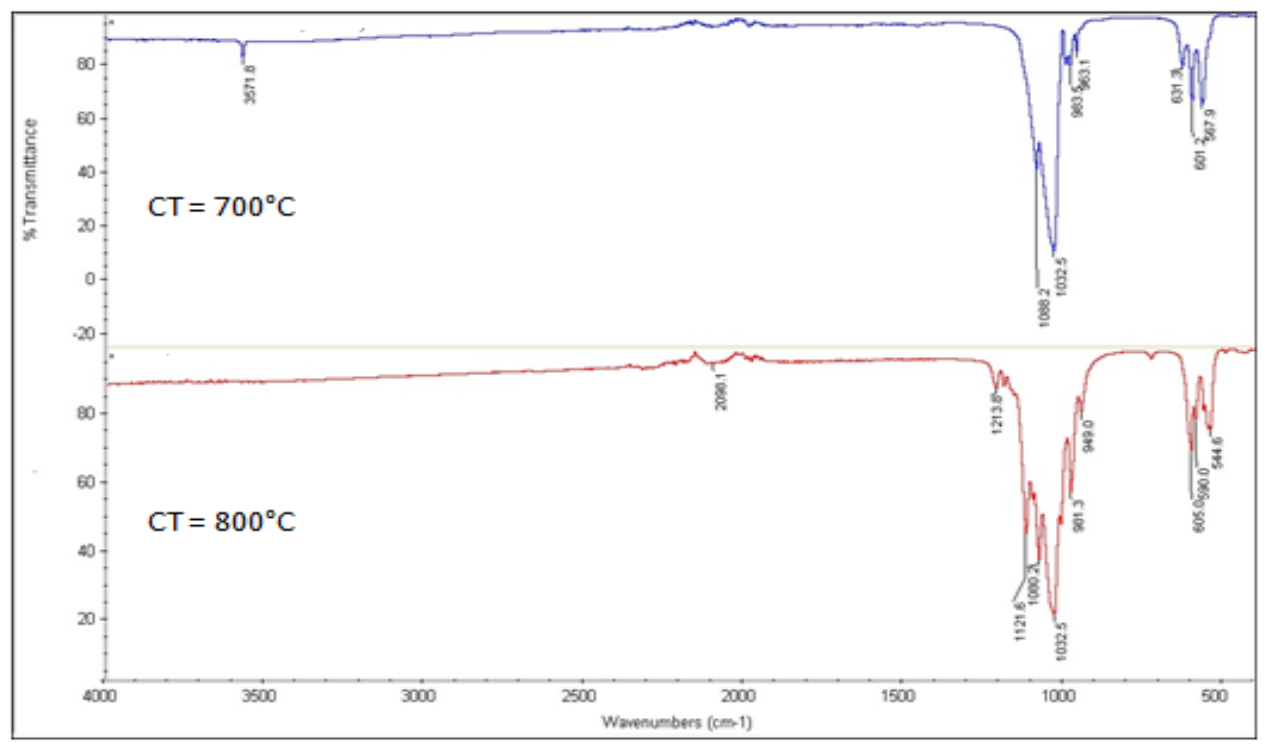

Figure 8. FT-IR spectra of nano $\mathrm{HA}$ at $\mathrm{pH} 9.00$ and reaction temperature $80^{\circ} \mathrm{C}$

The morphology of hydroxyapatite crystal: Effect of initial $\mathrm{pH}$ value

From the FESEM analysis of HA particle that shown in Figure 9 and Figure 10 below show that initial $\mathrm{pH}$ value play an important role in morphology controlling HA particle. The HA that synthesis at $\mathrm{pH} 9.00$ have sphere - like nano particle where the size of the particle about $209.9 \mathrm{~nm}$. For nano particle HA at $\mathrm{pH} \mathrm{10}$, the particle look like needle with average size $42.43 \mathrm{~nm}$. For the research conduct by Abidi and Murtaza [8], at pH 10.00 and 11.00, the $\mathrm{HA}$ is sphere-like nano particle with narrow distribution range and good dispersibility at $\mathrm{pH} 10.00$ where at $\mathrm{pH}$ 8.00 , the shape of HA is needle-like.

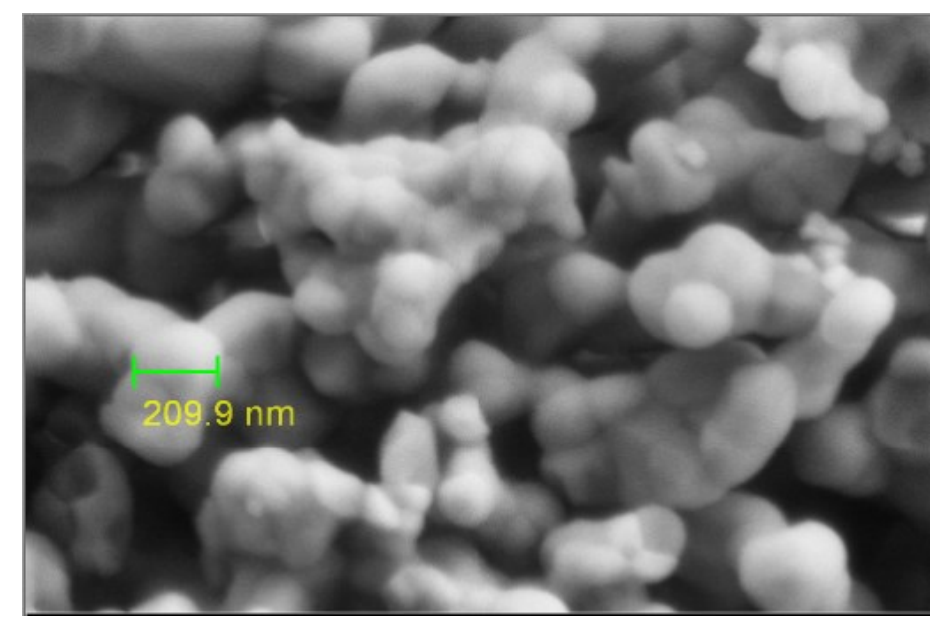

Figure 9. FESEM image for $\mathrm{HA}$ at $\mathrm{pH} 9.00$ 


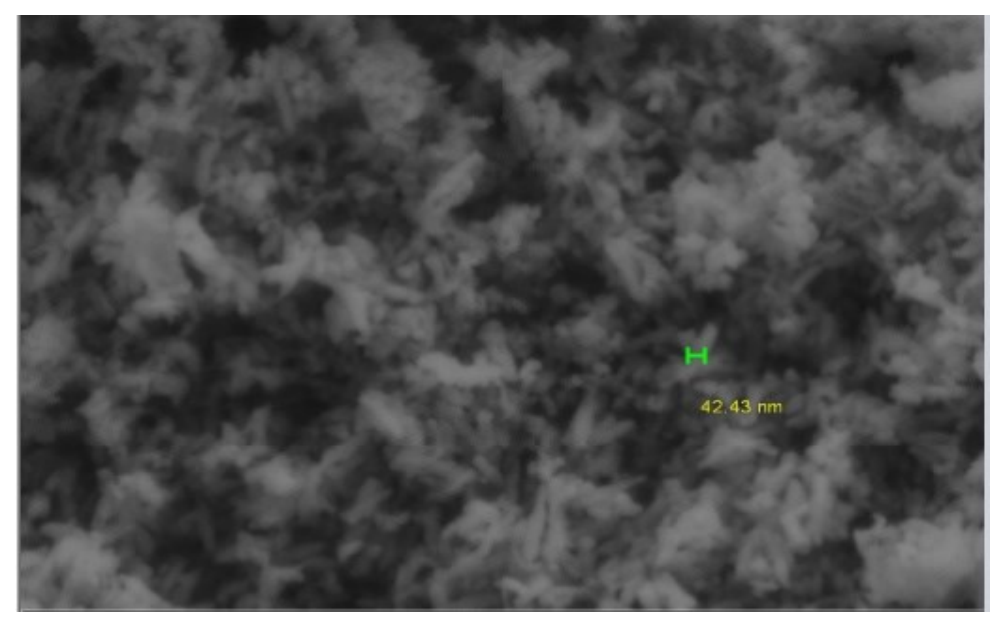

Figure 10. FESEM image for $\mathrm{HA}$ at $\mathrm{pH} 10.00$

\section{Effect of reaction temperature}

The reaction temperature is an important factor in synthesis HA where it can affect the morphology of HA. Nanoparticle of HA can be exhibit in various morphologies which are needle-like and spherical-like, both shape is common and suitable used in many type of technologies application. The natural bone is composed of needle-like nanoparticle and because of that the synthesis of nanoparticle HA in needle-like shape is timely needed requirement [8]. In Figure 11 and Figure 12, the shape of the crystal is different where nanoparticle HA that prepare at temperature $80^{\circ} \mathrm{C}$ has almost needle-like shape with $42.43 \mathrm{~nm}$ size where at reaction temperature $100^{\circ} \mathrm{C}$ it clearly shows the shape of the crystal is needle-like with size of the particle $58.06 \mathrm{~nm}$. It shows that the temperature is an important role in morphology of HA.

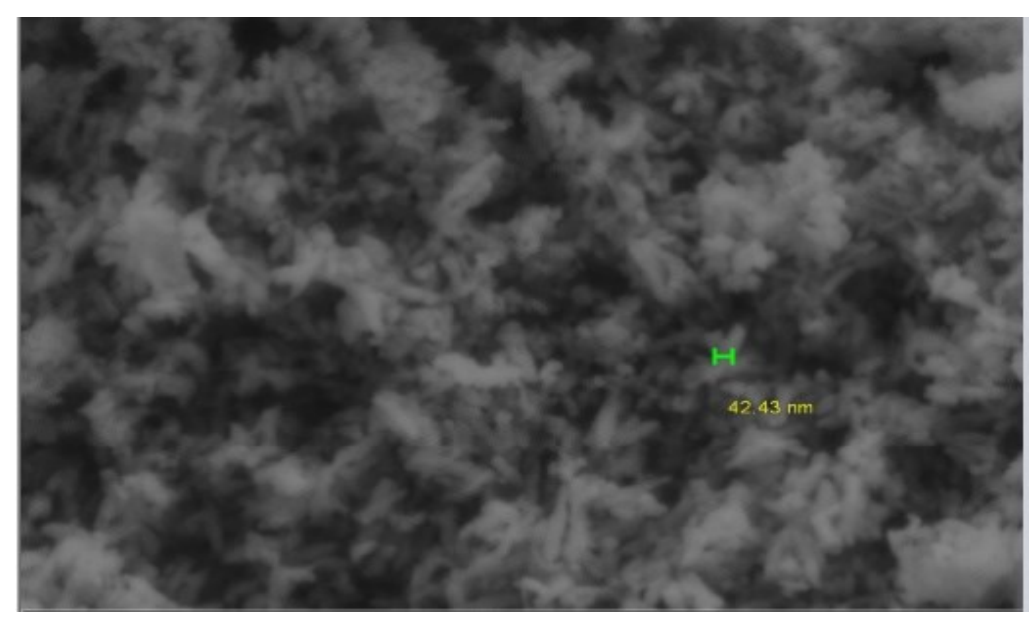

Figure 11. FESEM image for HA at reaction temperature $80{ }^{\circ} \mathrm{C}$ 


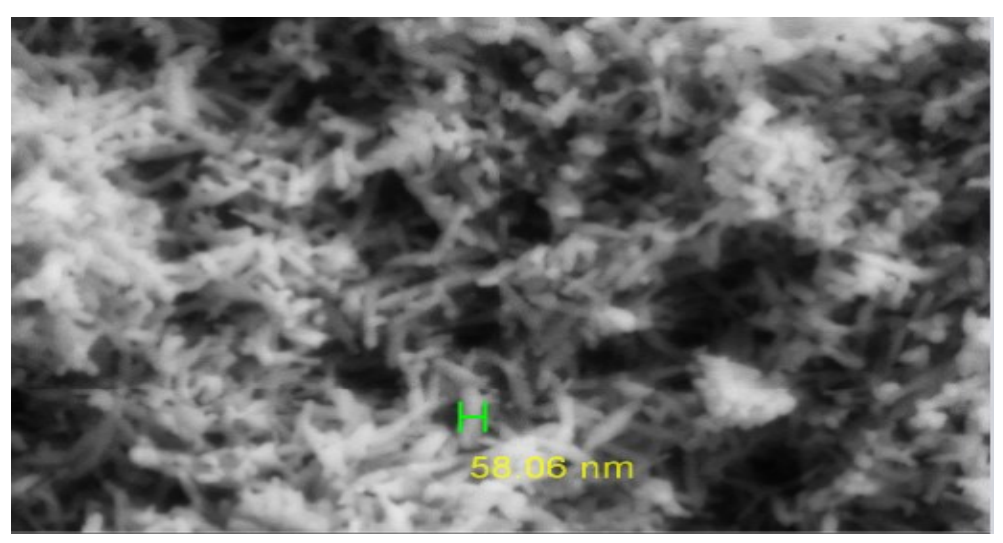

Figure 12. FESEM image for $\mathrm{HA}$ at reaction temperature $100^{\circ} \mathrm{C}$

\section{Effect of calcined temperature}

FESEM observation was performed to record the image of nanoparticle HA at calcined temperature $700{ }^{\circ} \mathrm{C}$ and $800^{\circ} \mathrm{C}$. It is well known that spherical powder has better rheological properties compared to irregular powder and lead to produce better coating for hip implant. In order to produce high quality of powder for hip implant it's very important to control granule spherical morphology. It has been demonstrated by increase temperature cause HA precipitate size increase [8]. In Figure 13 and Figure 14, it can be observed that nanoparticle HA will give different shape when calcined at different temperature. At $700^{\circ} \mathrm{C}$, the nanoparticle $\mathrm{HA}$ is needle-like shape with particle size $82.63 \mathrm{~nm}$ where at $800^{\circ} \mathrm{C}$ is spherical-like shape with particle size $227.8 \mathrm{~nm}$ These two shape is most popular in medical application. Different synthesis condition is performing according to the application.

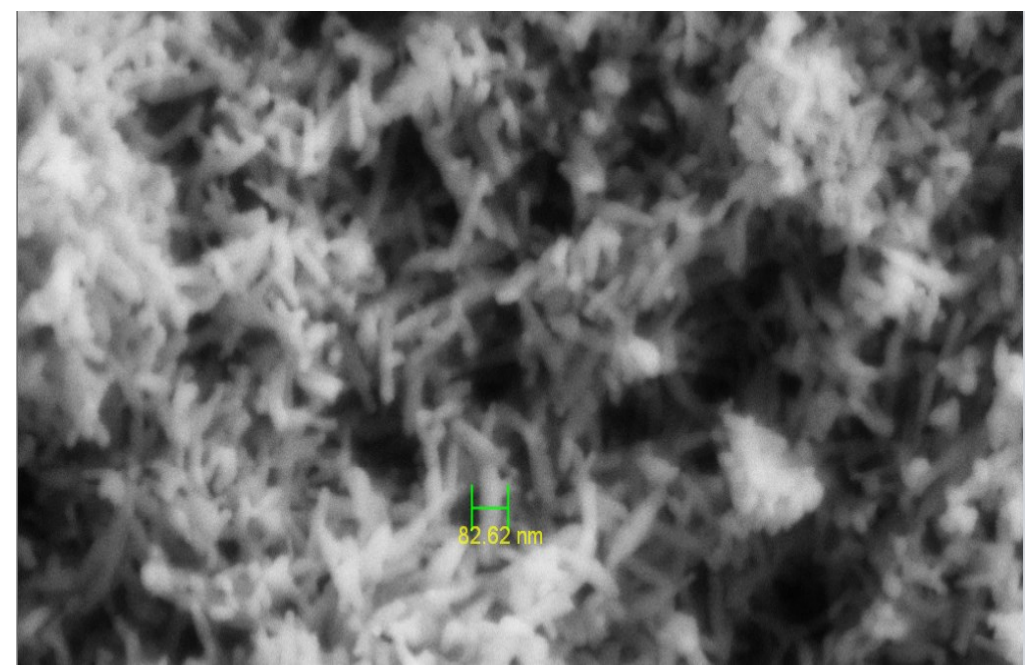

Figure 13. FESEM image for $\mathrm{HA}$ at calcined temperature $700{ }^{\circ} \mathrm{C}$ 


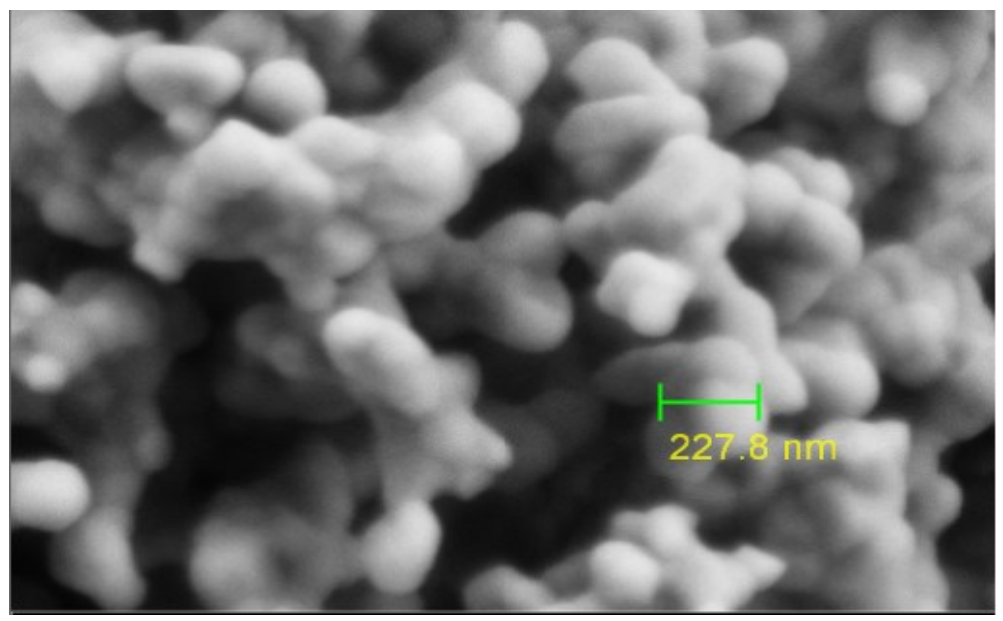

Figure 14. FESEM image for $\mathrm{HA}$ at calcined temperature $800^{\circ} \mathrm{C}$

\section{Design of Experiment (DOE): Statistical analysis}

For the three examined factors the CCD model efficiently designed a second order response to fit the surface. According to the design, the mass of synthesis HA was determined at different combination of parameters in order to evaluate the combined effect of these factors. The model used in this analysis was quadratic model. The degree of significance of each factor is represented in the table by its p-value. When a factor has a p-value of less than 0.05 $(\mathrm{P}<0.05)$, it indicates model terms are significant with a confidence level of 0.95 [9]. The test result for Analysis of Variance (ANOVA) test for RSM parameter was shown in Table 1. From the table, F-value for model is 4.18 with p-value less than 0.05 which indicate model term are significant under selected condition. In this case, parameter $\mathrm{C}$ which is calcined temperature is a significant model term with p-value 0.0017 .

Table 1. ANOVA for RSM parameter

\begin{tabular}{lccccc}
\hline Source & $\begin{array}{c}\text { Sum of } \\
\text { Squares }\end{array}$ & df & $\begin{array}{c}\text { Mean } \\
\text { Square }\end{array}$ & F Value & $\begin{array}{c}\text { p-value } \\
\text { (Prob }>\text { F })\end{array}$ \\
\hline Model & 38.52 & 9 & 4.28 & 4.18 & 0.0363 \\
A (reaction temperature) & 0.67 & 1 & 0.67 & 0.65 & 0.4465 \\
B (pH) & 0.10 & 1 & 0.10 & 0.10 & 0.7592 \\
C (Calcined temperature) & 24.90 & 1 & 24.90 & 24.33 & 0.0017 \\
AB & $9.800 \mathrm{E}-003$ & 1 & $9.800 \mathrm{E}-003$ & $9.575 \mathrm{E}-003$ & 0.9248 \\
$\mathrm{AC}$ & 0.22 & 1 & 0.22 & 0.21 & 0.6586 \\
$\mathrm{BC}$ & 0.54 & 1 & 0.54 & 0.53 & 0.4909 \\
$\mathrm{~A}^{2}$ & 0.56 & 1 & 0.56 & 0.54 & 0.4847 \\
$\mathrm{~B}^{2}$ & 1.53 & 1 & 1.53 & 1.50 & 0.2609 \\
$\mathrm{C}^{2}$ & 1.96 & 1 & 1.96 & 1.92 & 0.2086 \\
\hline
\end{tabular}

ANOVA result for response parameter are shown in Table 2 . The value of $\mathrm{R}^{2}$ provide a measure how much variation in the observed response value can be explained by the experimental factor and their interaction. The value of $\mathrm{R}^{2}$ is always between 0 to 1 . The closer $\mathrm{R}^{2}$ value to 1 , the stronger the model is and better it predict the response [9]. The value for $\mathrm{R}^{2}$ for this test is 0.843 . 
Table 2. ANOVA result for response parameter

\begin{tabular}{cclc}
\hline Std. Dev. & $\mathbf{1 . 0 1}$ & $\mathbf{R}^{\mathbf{2}}$ & $\mathbf{0 . 8 4 3}$ \\
\hline Mean & 7.61 & Adj R $^{2}$ & 0.641 \\
C.V. $\%$ & 13.30 & Pred R $^{2}$ & -0.337 \\
PRESS & 61.08 & Adeq Precision & 6.686 \\
\hline
\end{tabular}

Response surface methodology is use to trace the efficiently for the optimum value of the significant variable. In this research the focus in this study to optimize the parameter used which are reaction temperature, $\mathrm{pH}$ value and calcined temperature respect to mass of HA formed from synthesis process. In Figure 15, it shows the optimum $\mathrm{pH}$ value which is at $\mathrm{pH} 9.00$ and the reaction temperature is at $90^{\circ} \mathrm{C}$.

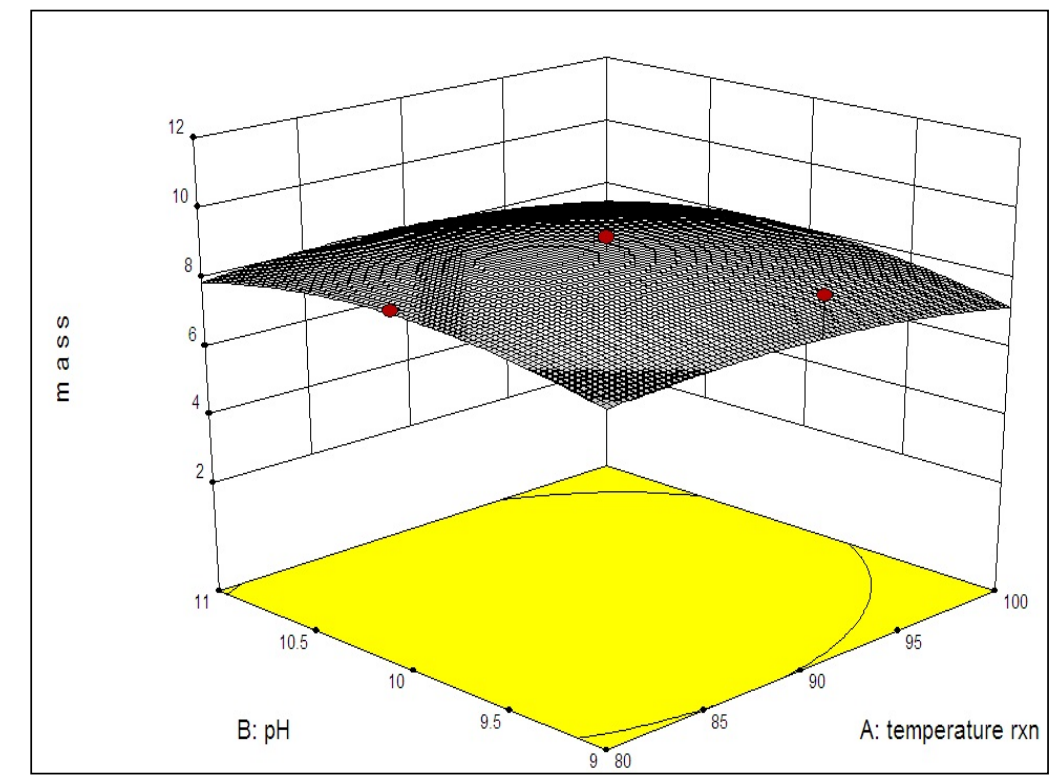

Figure 15. Response surface plot for combined variable $\mathrm{pH}$ value and temperature reaction

Table 3 shows the result for experimental and predicted mass of nanoparticle HA based on ANOVA. The predicted mass of HA differ from experimental result where the highest mass was predicted at $90{ }^{\circ} \mathrm{C}, \mathrm{pH} 10.00$ and $700{ }^{\circ} \mathrm{C}$ which is $9.54 \mathrm{~g}$. Equation below is the linear corelation related the variables that influence the mass of HA formed from synthesis process

$$
\begin{aligned}
\text { Mass }= & 8.82-0.26 . A+0.10 . B-1.58 . C+0.0135 A . B-0.16 A . C+0.26 B . C-0.46 A^{2}-0.76 B^{2} \\
& -0.86 C^{2}
\end{aligned}
$$

A positive sign in the equation above represent a synergetic effect of the variable and negative sign represnet an antagoniistic effect of the variable. 
$\begin{array}{ll}\text { Sahlil Miraz \& Darman: } & \text { SYNTHESIS AND CHARACTERIZATION OF HYDROXYAPATITE } \\ \text { NANOPARTICLE }\end{array}$

Table 3. Result for experimental and predicted mass of HA

\begin{tabular}{lccccc}
\hline Run & $\begin{array}{c}\text { Factor } \mathbf{1} \\
\text { A: Reaction } \\
\text { T }\left({ }^{\circ} \mathbf{C}\right)\end{array}$ & $\begin{array}{c}\text { Factor } \mathbf{2} \\
\text { B: pH }\end{array}$ & $\begin{array}{c}\text { Factor 3 } \\
\mathbf{C}: \text { Calcined } \\
\left.\text { T( }{ }^{\circ} \mathbf{C}\right)\end{array}$ & $\begin{array}{c}\text { Experimental } \\
\text { Mass } \\
(\mathbf{g})\end{array}$ & $\begin{array}{c}\text { Predicted } \\
\text { Mass } \\
(\mathbf{g})\end{array}$ \\
\hline 1 & 90 & 10.00 & 800 & 6.12 & 6.39 \\
2 & 80 & 9.00 & 700 & 8.00 & 8.62 \\
3 & 90 & 11.00 & 700 & 6.42 & 8.17 \\
4 & 80 & 10.00 & 700 & 8.72 & 8.63 \\
5 & 100 & 10.00 & 700 & 7.42 & 8.11 \\
6 & 90 & 9.00 & 700 & 9.12 & 7.97 \\
7 & 90 & 10.00 & 700 & 9.22 & 9.54 \\
8 & 90 & 10.00 & 700 & 9.22 & 8.82 \\
9 & 100 & 11.00 & 800 & 5.92 & 5.15 \\
10 & 100 & 9.00 & 700 & 8.42 & 8.36 \\
11 & 80 & 9.00 & 800 & 5.12 & 5.27 \\
12 & 100 & 11.00 & 700 & 8.42 & 8.12 \\
13 & 100 & 9.00 & 800 & 3.92 & 4.36 \\
14 & 80 & 11.00 & 700 & 8.82 & 8.23 \\
15 & 80 & 11.00 & 800 & 6.02 & 5.93 \\
16 & 90 & 10.00 & 700 & 9.22 & 9.54 \\
17 & 90 & 10 & 700 & 9.22 & 8.82 \\
\hline
\end{tabular}

\section{Conclusion}

The study of three tested parameters which are reaction temperature, $\mathrm{pH}$ value and calcined temperature were investigate and it show these parameters have significant effect on mass of HA formed, the characteristic and the morphology of the nanoparticle that synthesis using wet chemical precipitation method. Wet chemical precipitation method was used due to its reproducibility, simplicity and economical. The analysis of XRD, FTIR and FESEM show that all sample are in nanoparticle size. From the XRD pattern, the highest crystallinity occurs at condition reaction temperature $100{ }^{\circ} \mathrm{C}, \mathrm{pH}$ value 10.00 and calcined temperature $800{ }^{\circ} \mathrm{C}$. The spectra of FTIR show all the sample contain HA and from the image FESEM, nanoparticle HA formed from this research is needle-like and spherical-like with the range particle size between 40 to $200 \mathrm{~nm}$. Optimization of parameters in synthesis of nanoparticle HA was determined using Design expert version 9.0.2. Based on analysis of variance (ANOVA) that has been perform, calcined temperature was to be influential variables on mass of HA with value of probability less than 0.05 .

\section{Acknowledgement}

The author would like to acknowledge Universiti Kebangsaan Malaysia (DIP-2014-014 and IP-2014-018) for supporting this research project.

\section{References}

1. Eshtiagh-Hosseini, H., Housaindokht, M. R. and Chahkandi, M. (2007). Effects of parameters of sol-gel process on the phase evolution of sol-gel-derived hydroxyapatite. Materials Chemistry and Physics, 106(2): $310-316$.

2. Feng, W., Mu-Sen, L., Yu-Peng, L. and Yong-Xin, Q. (2005). A simple sol-gel technique for preparing hydroxyapatite nanopowders. Materials Letters, 59(8): 916 - 919. 
3. Yin, G., Liu, Z., Zhan, J., Ding, F. and Yuan, N. (2002). Impacts of the surface charge property on protein adsorption on hydroxyapatite. Chemical Engineering Journal, 87(2): 181 - 186.

4. Kramer, E., Podurgiel, J. and Wei, M. (2014). Control of hydroxyapatite nanoparticle morphology using wet synthesis techniques: Reactant addition rate effects. Materials Letters, 131: $145-147$.

5. Mostafa, A. A., Oudadesse, H., Mohamed, M. B., Foad, E. S., Le Gal, Y. and Cathelineau, G. (2009). Convenient approach of nanohydroxyapatite polymeric matrix composites. Chemical Engineering Journal, 153(1): $187-192$.

6. Wang, P., Li, C., Gong, H., Jiang, X., Wang, H. and Li, K. (2010). Effects of synthesis conditions on the morphology of hydroxyapatite nanoparticles produced by wet chemical process. Powder Technology, 203(2): $315-321$.

7. Wijesinghe, W. P. S. L., Mantilaka, M. M. M. G. P. G., Premalal, E. V. A., Herath, H. M. T. U., Mahalingam, S., Edirisinghe, M., Rajapakse, R. P. V. J. and Rajapakse, R. M. G. (2014). Facile synthesis of both needle-like and spherical hydroxyapatite nanoparticles: Effect of synthetic temperature and calcination on morphology, crystallite size and crystallinity. Materials Science and Engineering: C, 42: 83 - 90.

8. Abidi, S. S. A. and Murtaza, Q. (2014). Synthesis and characterization of nano-hydroxyapatite powder using wet chemical precipitation reaction. Journal of Materials Science \& Technology, 30(4): 307 -310.

9. Stanić, V., Dimitrijević, S., Antonović, D. G., Jokić, B. M., Zec, S. P., Tanasković, S. T. and Raičević, S. (2014). Synthesis of fluorine substituted hydroxyapatite nanopowders and application of the central composite design for determination of its antimicrobial effects. Applied Surface Science, 290: 346 - 352. 